Acta vet. scand. $1960,1,245-249$.

From the Department of Anatomy and Histology, Royal Veterinary

College, Stockholm.

\title{
DEVELOPMENTAL ANOMALIES OF THE DUODENUM AND THE GREATER OMENTUM IN A SHEEP
}

By

Gösta Winquist.

A group of seven apparently healthy sheep, about 10 months old, had been killed and embalmed with formalin for teaching purposes. When the abdominal cavity was opened, one of the animals exhibited some striking anomalies, which can be deduced from disturbances in early development and thus might help in understanding the normal conditions. For that reason and because of the fact that no similar case has been reported in the available literature, the anomalies will be described briefly.

The animal was a female of the same size and nutritional state as the rest of the group. The most impressive anomaly was noted on the small intestine which ran directly from the pylorus along the visceral surface of the liver to form typical jejunal coils at the perihery of the spiral mass formed by the large intestine. (Figs. 1-3). The first part of the small intestine was S-shaped and attached to the liver by the lesser omentum in a normal way (Fig. 1). The bile duct opened into it at $18 \mathrm{~cm}$ distance from the pylorous. Microscopical examination revealed that duodenal glands were present to the opening of the bile duct but not beyond that point. This part of the intestine corresponds to the S-shaped first part of the duodenum in normal sheep. In normal mammals the duodenum continues backwards along the right abdominal wall and extends forwards on the left side of a. mes. cran. to join the jejunum. This loop was entirely missing here. It is well known that the loop is formed at an early embryonic stage by rotation of the mid gut. During this rotation 


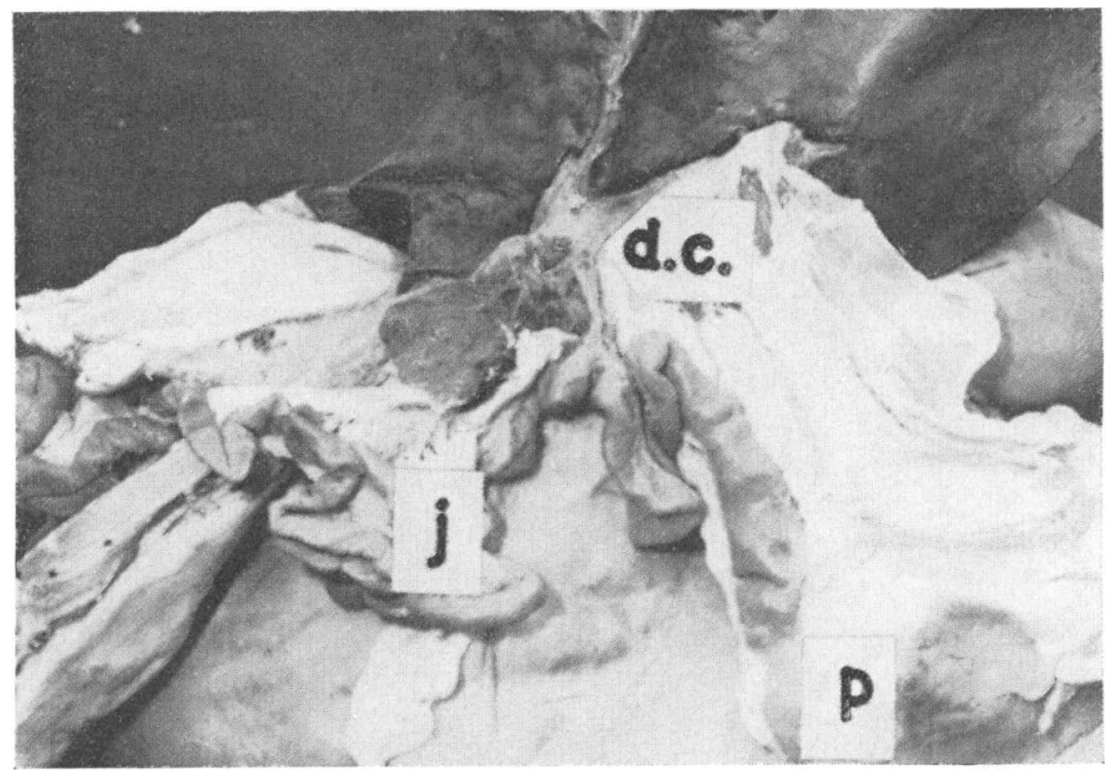

Fig. 1. Ventral view of pyloric region, duodenum, lesser omentum, and liver. Note duodenum running from pylorus (p.) to the opening of the bile duct (d.c.) and then directly joining the jejunum (j.).

the colon normally forms a loop passing cranially to the cranial mesenteric artery with the oral part to the right and the aboral part to the left of the artery. This loop was also missing, the whole colon being situated to the left of the artery and its larger ramifications. It is thus obvious that the embryonic rotation of the mid gut had not taken place in this case. The colon spiral, on the other hand, had a normal shape and position.

The greater omentum passes the intestinal mass ventrally, in normal sheep as well as other ruminants, and both its lamina are attached to the right (lateral) surface of the intestinal mass just below the duodenum, thus forming the characteristic bursa supraomentalis. In this case, it had a normal attachment to the rumen, the greater curvature of the abomasum, and the initial part of the duodenum, but instead of passing ventrally to the intestinal mass it was attached to the left (medial) side, mainly on the ansa proximalis of the colon (Fig. 2 and 3). Because of the abnormal attachment of the greater omentum the whole intestine was left uncovered by the omentum and no true bursa supraomentalis was present. 


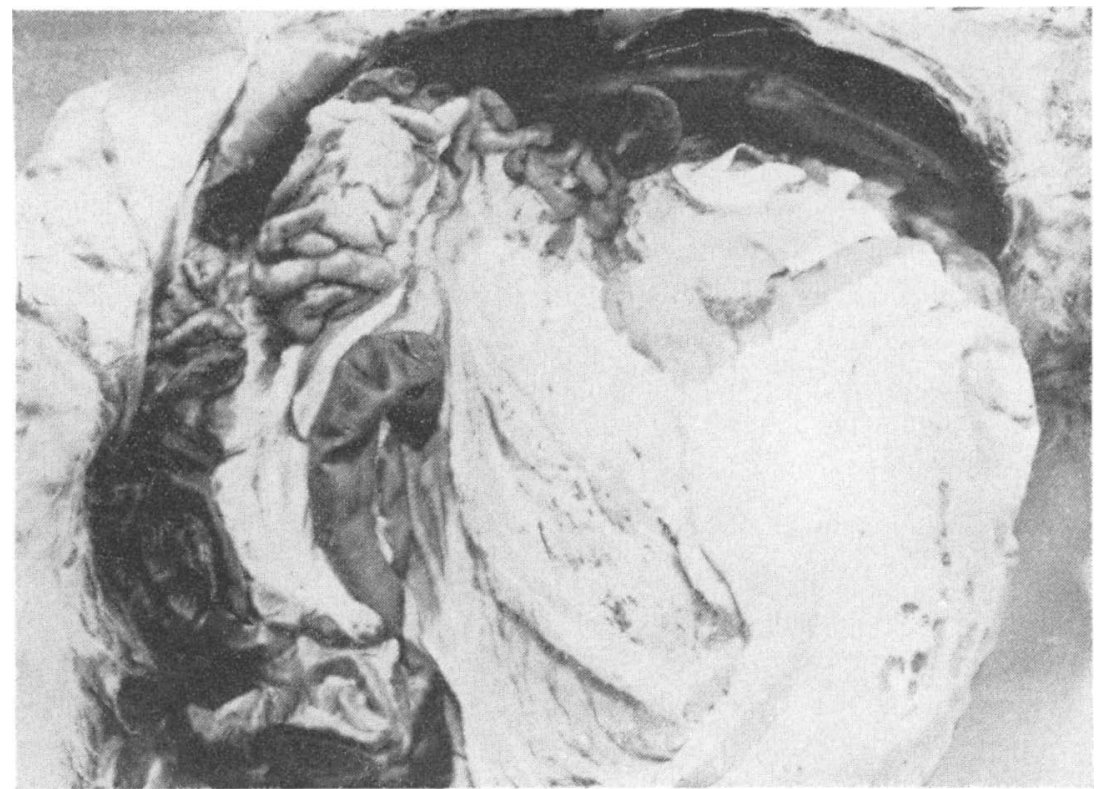

F i g. 2. Ventral view of abomasum, rumen, and intestinal mass. Note attachment of the greater omentum medially to the intestinal mass.

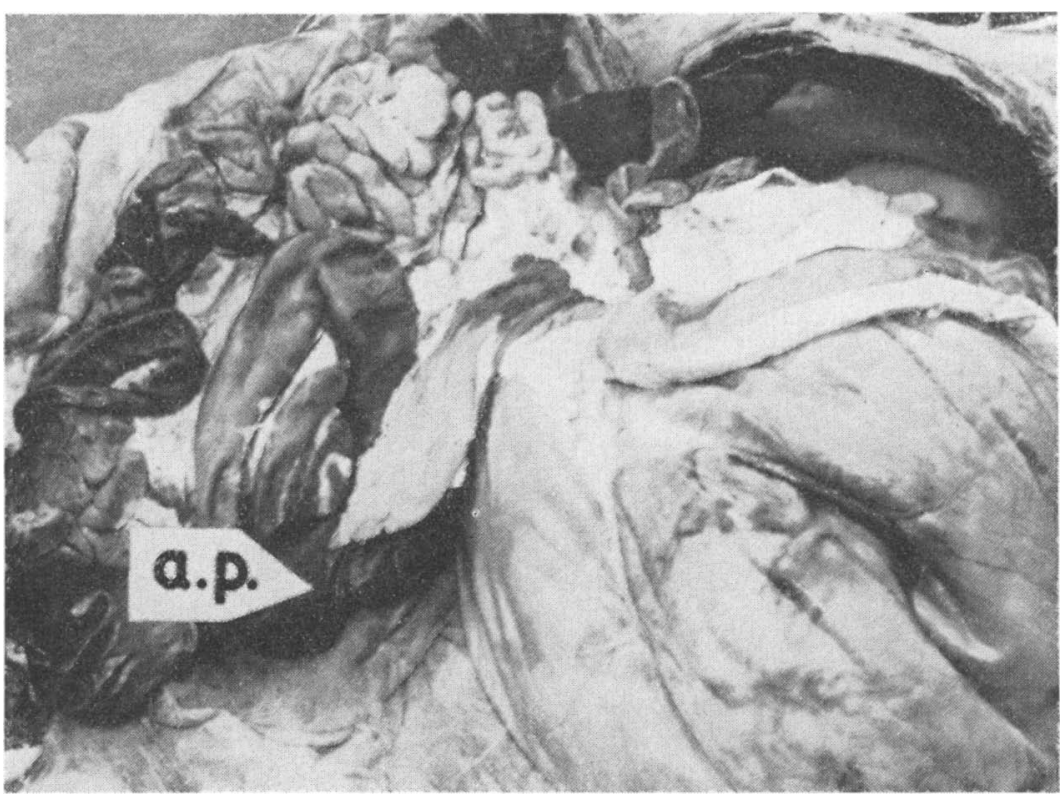

Fig. 3. Caudo-ventral view of abomasum, rumen, and intestinal mass. The greater omentum has been removed almost completely. Note attachment to the proximal ansa (a.p.) of colon. 


\section{COMMENTS}

The primary abnormality seems to be the non-rotation of the mid gut accompanied by a considerable reduction of the duodenum. In spite of the fact that the development and topography of the digestive tract in sheep has been studied extensively Corsy (1), Ellenberger and Schaaf (2), Florentin (4), Hafner (6), Martin (7), Wilkens (9) no similar case has been reported. To judge from the literature this anomaly is very rare in other animals, too, but in man it has been observed in many instances since 1862 (Gruber (5)).

Smith (8) gives an incidence of 0.5 per cent in anatomically studied specimens. For a comprehensive review of human cases the reader is referred to Estrada's (3) recent monograph. In most instances the anomaly had not caused any clinical symptoms but was noted during radiological examination or laparotomy for other reasons or at autopsy. In these cases, as in the sheep reported here, it seems reasonable to consider the non-rotation of the mid gut as a harmless anatomical variation.

The reduction of the duodenal glands to the first $18 \mathrm{~cm}$ of the small intestine against the normal $60-70 \mathrm{~cm}$ is very likely to be secondary to the reduction of the duodenum as they are known to develop after duodenum has achieved its normal extent Zietschmann and Krölling (10).

This reduction is interesting from the point of view that the sheep, among all domestic mammals, is the only one showing good agreement between the duodenum by histological definition (appearance of duodenal glands) and the anatomical duodenum (part of small intestine between the pylorus and the flexura duodeno-jejunalis).

Obviously the non-rotation of the embryonic mid gut has had no influence on the formation of the colon spiral and connected structures.

The abnormal attachment of the greater omentum which was here of a primitive type as occurs in carnivores deserves particular interest, as it strongly indicates that a normal course of the duodenum is necessary for the development of the typical bursa supraomentalis. 


\section{REFERENCES}

1. Corsy, F.: C. r. ass. anat. $1935,30,115$.

2. Ellenberger, W. \& A. Schaaf: Dtsch. Z. Tiermed. 1884, 10, 1.

3. Estrada, R. L.: Anomalies of Intestinal Rotation and Fixation. Charles C. Thomas, Springfield, Illinois, 1959.

4. Florentin, P.: Rev. méd. vet. 1955, $106,657$.

5. Gruber, W.: Arch. Anat. Physiol. u. wissenschaft. Med. 1862, p. 588.

6. Hafner, B.: Die Entwicklung der Lage und Anordnung des Schweine- und Wiederkäuerdarmes. Diss. Giessen, 1909.

7. Martin, P.: Österreich. Mschr. f. Tierheilk. 1897, 22, 49, 97 and 145.

8. Smith, G. M.: Anat. Rec. 1911, 5, 549.

9. Wilkens, H.: Z. bl. f. Vet.-Med. 1956, 3, 803.

10. Zietschmann, O. \& O. Krölling: Lehrbuch der Entvicklungsgeschichte der Haustiere, 2nd Ed. Paul Parey, Berlin, 1955.

\section{SUMMARY}

A case of non-rotation of the mid gut in a sheep is described, resulting in a reduction of the duodenum and an abnormal attachment of the greater omentum.

\section{ZUSAMMENFASSUNG}

Entwickelungsanomalien des Duodenums und des grossen Netzes eines Schafes.

Ein Fall von ausgebliebenen Drehung der embryonalen Darmschleife beim Schaf mit Reduktion von Duodenum und abnormer Insertion des grossen Netzes wird beschrieben.

\section{SAMMANFATTNING}

Utvecklingsanomalier av Duodeum och stora nätet hos får.

Ett fall av utebliven embryonal rotation av mellantarmen hos får med reduktion av Duodenum och abnormt fäste för stora nätet beskrives.

(Received January 18. 1960). 